\title{
IUPAC Wire
}

\section{IUPAC recognized by OPCW}

\section{$\mathrm{T}$} he Director-General of the Organisation for the Prohibition of Chemical Weapons (OPCW), H.E. Mr Fernando Arias, is pleased to announce the decision of the OPCW-The Hague Award Committee to honour Robert Mikulak (US); Cheng Tang (China); and IUPAC as joint recipients of the 2019 OPCW-The Hague Award.

Mikulak and Tang have both been extensively involved in the negotiations of the Chemical Weapons Convention (CWC) and have collaborated with the OPCW on a broad range of topics. IUPAC has contributed to providing the OPCW with objective scientific knowledge on emerging areas of science related to the CWC, as well as carrying out education and outreach activities to chemistry practitioners and the general public.

The OPCW-The Hague Award is a legacy of the OPCW receiving the 2013 Nobel Prize for Peace and it recognises individuals and institutions that make an outstanding contribution towards the goals of the CWC. The Award was established in 2014 from the monetary prize accompanying the Nobel Prize for Peace and is supplemented by the City of The Hague. The award ceremony was held on 25 November 2019 in The Hague, during the first day of the Twenty-Fourth Conference of the States Parties to the Chemical Weapons Convention, and IUPAC Vice President Professor Christopher Brett received the Award on behalf of the Union.

\section{Chemical Weapons Convention Amended}

\section{by Leiv K. Sydnes}

When the Chemical Weapons Convention (CWC) was finalized in 1992, a world with no production, storage and use of such weaponry was envisaged. But in spite of the fact that almost all chemical weapons have been destroyed ( $97 \%$ by now) and chemical warfare by conventional thinking should have become almost unlikely, incidents involving such weapons have increased in numbers and scale in recent years. This has indeed had an impact, and ordinary citizens now seem to regard chemical weapons more of a threat than a few years back. The main reasons for this are serious reports from Syria, where chemical weapons have been part of the war theatre more or less regularly since 2012, but the assassination of Kim Jong-nam by $V X$ at the airport in Kuala Lumpur, Malaysia, and the attack of Sergei Skripal, a former Russian agent, and his daughter

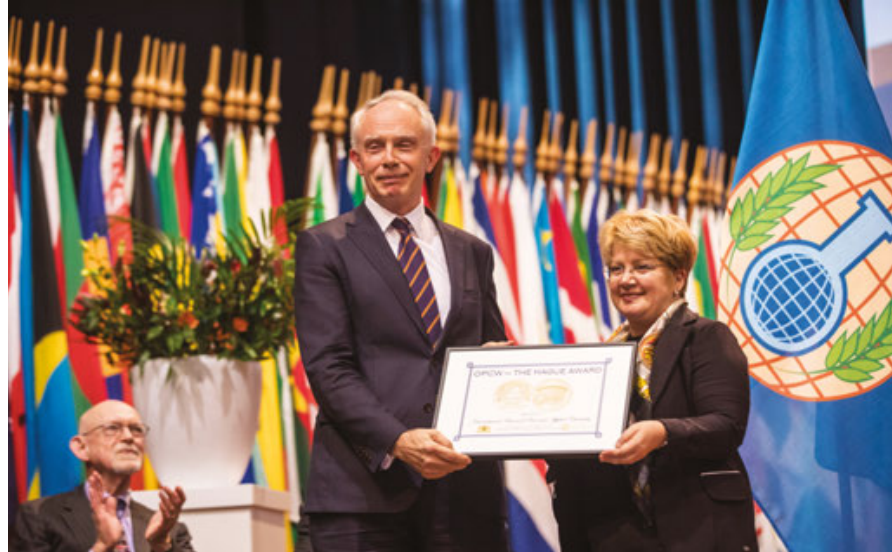

On behalf of IUPAC, Vice President Christopher Brett (left), accepts the 2019 OPCW-The Hague award from Romanian Ambassador to OPCW Brândușa Predescu, Vice Chairperson of the Executive Council.

\section{Learn More}

For a recent account of IUPAC's commitment to supporting the norms of disarmament, see this IUPAC100 story by J. Forman and M. Cesa; https://iupac.org/100/ stories/a-partnership-of-science-and-diplomacyto-eliminate-chemical-weapons/

See also project 'Building broader and deeper links between OPCW and IUPAC; https://iupac.org/ project/2018-022-3-020.

https://iupac.org/iupac-is-one-of-the-recipients-of-the-2019-opcw-thehague-award/

Julia with novichok, the most deadly nerve agent known [1], in Salisbury, UK, have also left disturbing impressions. An obvious question has therefore emerged, also within the Organization for the Prohibition of Chemical Weapons (OPCW), established to implement the CWC: What can be done to stop this destructive development once and for all? Possible solutions seem to have been<smiles>CN(C)C(=NP(C)(=O)Oc1ccccc1)N(C)C</smiles><smiles>CCN(CC)C(C)=NP(C)(=O)F</smiles>

Two examples of novichoks discussed ever since the CWC went into force in 1997 and particularly in preparation of and in connection with the reviews of the Convention, which have taken place every fifth year since 2003. One issue in this discussion has been the value of expanding the list of chemical compounds mentioned specifically in the Convention. 
An argument against such an expansion has been that enlisting a chemical does not change anything since all chemicals that are used to kill people by definition become chemical weapons. This indeed curbed the discussion for about 25 years-until last month. When the States Parties assembled in The Hague to their 24th session at the end of November last year, the CWC was amended for the first time ever. The amendment amounted to adding of a series of novichoks (see Figure) to the annex on chemicals to the Convention, as proposed by Canada, United States and the Netherlands [2]. For many chemists, this addition will make them aware of a new structural feature to watch out for in a chemical-weapons context, the $\mathrm{O}=\mathrm{P}-\mathrm{N}$ moiety, but the novichoks are chemical weapons weather they are listed or not, so their inclusion has no practical consequence really [3]. However, from a diplomatic point of view the amendment looks different. Thus, the Director-General of OPCW, H.E. Mr Fernando Arias, made the point that this amendment is important because it "demonstrates the adaptability of the Convention to changing threats while enhancing the OPCW's ability to remain vigilant, agile, and fit for purpose [4]."

\section{References}

1. See en.wikipedia.org/wiki/Novichok_agent (18.12.19)

2. See www.federalregister.gov/ documents/2019/08/14/2019-17256/impact-ofproposed-additions-to-the-annex-on-chemicals-to-thechemical-weapons-convention-cwc-on

3. See a news release in Nature 28 November 2019 , https://www.nature.com/articles/d41586-019-03686-y

4. Press release from OPCW 27 November 2019; www. opcw.org

Leiv K. Sydnes <leiv.sydnes@uib.no> is professor emeritus at Department of Chemistry, University of Bergen, Norway. He was president of IUPAC 2004-2005 and chaired the IUPAC CHEMRAWN committee in 2008-2015, and actively involved in collaboration with OPCW since 2002.

IUPAC-SOLVAY International Award for Young ChemistsCall for Nominations

\section{SOLVAY}

asking more from chemistry*

FONDS Einest SOLVAY

\section{$T$} he IUPAC-SOLVAY International Award for Young Chemists is intended to encourage outstanding young research scientists at the beginning of their careers. The awards are given for the most outstanding Ph.D. theses in the general area of the chemical sciences, as described in a 1000-word essay. The award is generously sponsored by Solvay.

In 2020 IUPAC will award up to five prizes. Each prize will consist of USD 1000 cash and travel expenses to the 2021 IUPAC Congress in Montréal, Canada (13-20 Aug 2021; iupac2021.org). In keeping with IUPAC's status as a global organization, efforts will be made to ensure fair geographic distribution of prizes. The awards will be presented at the 2021 IUPAC Congress. Each awardee will be invited to present a poster on his/her research and to participate in a plenary award session, and is expected to submit a review article for publication in Pure and Applied Chemistry.

Application deadline 15 February 2020

https://iupac.org/2020-iupac-solvay-international-award-for-young-chemists/

\section{BIPM and IUPAC formalize a long- standing cooperation}

UPAC has signed a Memorandum of Understanding
with the Bureau International des Poids

et Mesures (BIPM). Signed

on 17 October 2019 at the BIPM during the meeting of the National Metrology Institutes (NMI) Directors, the MoU formalizes the long-standing cooperation between the BIPM and IUPAC.

The BIPM-IUPAC Memorandum of Understanding was signed by Wynand Louw,

President of the CIPM, and by Chris-

\section{BIPM}

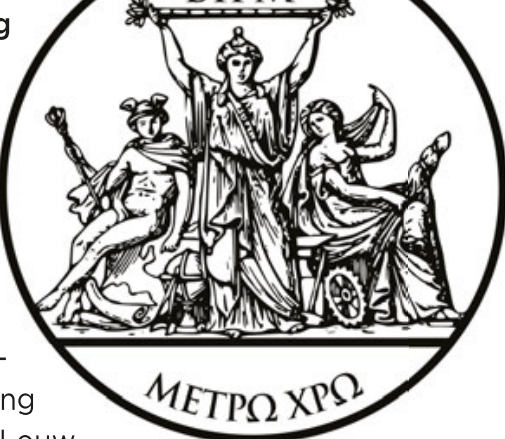

topher M.A. Brett, Vice President of IUPAC, on behalf of the IUPAC President, Qifeng Zhou.

The BIPM has for many years been represented on the IUPAC Interdivisional Committee on Terminology, Nomenclature and Symbols (ICTNS), and IUPAC participates in the Consultative Committee for Amount of Substance (CCQM), the Consultative Committee for Units (CCU), and the Joint Committee for Guides in Metrology (JCGM). 